\title{
Patent system gets vote of support from gene workers
}

Paris. The patent system is the 'mechanism of excellence' for commercializing the results of the human genome project. This was the unexpected consensus reached at an international meeting of leading genome scientists, industrialists and patent lawyers organized by the French Academy of Sciences in Paris last week.

The mood of the meeting was that the concern about patenting genes had now been allayed. "Patenting genes poses no specific problems," said Philippe Lazar, director general of the French biomedical research organization INSERM. But it had helped to prompt an overdue debate on the role of patents in research, technology transfer and the sharing of savoir-faire with developing countries.

"Patents are the instruments of partnership between science and the economy," said Lazar, summing up an enthusiasm for the patent system among researchers at a meeting which François Gros, the perpetual secretary of the academy, pointed out would have been unthinkable 15 years ago.

In particular, many felt that most of the current problems associated with patenting genes would disappear over time, particularly if patent offices simply applied the three existing criteria of patentability novelty, non-obviousness and utility - with greater rigour. Indeed, the meeting concluded that commercializing the genome does not require reinventing the internationally proven, 200-year-old patent system, but simply adapting it.

One major concern, said Thomas Caskey, president of the Human Genome Organization (HUGO), is that patenting partial or uncharacterized cDNAs "would reward those who make routine discoveries, but penalize those who determine biological function or application". This is not in the "public interest" he said.

"We've got to explain to lawyers that finding a gene [using routine techniques] is not inventive," said Jean Weissenbach from the French genome centre Généthon. "We all agree that genes can be patented when we know their function," added Maxime Schwartz, director general of the Pasteur Institute.

Patent lawyers told the meeting that patents whose function is unknown are unlikely to be refused on the grounds of lack of novelty. This criterion can be easily sidestepped, for example, by describing genes as "isolated, purified, and carried in a recombinant host". But they said that patents on such genes could be refused for lack of inventiveness - or nonobviousness - in particular as more and more genes are isolated.

Another related concern expressed at the meeting was the fairness of awarding a patent to the research group that places the final brick, for example the actual discovery of a specific gene, in a wall built by many others. Patent lawyers pointed out however, that the patent system exists only to promote innovation and not to guarantee equity among inventors.

But Schwartz argued that "we have to reduce the disparity between those who get the patent and those who did the work". One possibility would be royalty-sharing agreements. Schwartz proposed, for example, that such agreements are particularly needed in areas such as AIDS vaccines, where the low potential return, combined with the allor-nothing nature of competition, discourages investment.

But the lawyers dismissed researchers' concern that the granting of a patent to the discoverer of a gene would penalize those who subsequently carried out the more difficult task of working out what the gene does, and what it could be used for. They argued that there is no reason why a scientist should not obtain a separate patent on further uses of a gene, in much the same way as patent rights are now conferred on new applications of existing drug molecules.

Indeed, the meeting felt that recent attention given to the patentability of genes per se has detracted from the bigger problem of how such rights are enforced. The breadth of patents granted on gene technologies, and the terms under which patents are licensed, were identified as key issues.

Peter Kolken, for example, from the British pharmaceutical group Zeneca, argued that it was "normal" for patent offices to grant broad patents in the early days of a technology, and then to reduce the scope as the technology developed. Another pagent lawyer argued that the only way to find the real scope of a patent is to challenge it in court.

Moreover, even if patent offices grant excessively broad patents, the patent system can handle this, according to other patent lawyers. There is no reason why compulsory licences, for example, should not be invoked more often for important inventions concerning the genome.

Caskey also asked whether patents on genes might increase health-care costs unnecessarily and restrict access to therapies developed from the human genome project. He suggested that governments should intervene to regulate the level of royalties.

Jean Lunel, a research director at RhônePoulenc Rorer, asserted that such arguments show a misunderstanding of the patent system. Although patents reduce access to therapies for part of the population in the short term, he argued, without patents the whole population would be deprived of new drugs.

Declan Butler
Terms of HGS deal boost search for

\section{new strategies}

Paris. If patents are becoming more acceptable as a way of handling information about new genetic discoveries (left), this is partly due to reaction to the termsset by the US gene-sequencing company Human Genome Sciences Inc. (HGS) for university-based scientists seeking to work with sequences produced by HGS's Institute of Genomic Research (TIGR).

The agreement gives HGS first refusal on any patents arising from research using the database sequences (see Nature 371 ,

463; 1994).

This requirement has generated w i d e s p re ad criticism. "We've discovered that there is something worse than patents", said Bertrand Jordan, from the Centre d'Immunologie de Marseille-

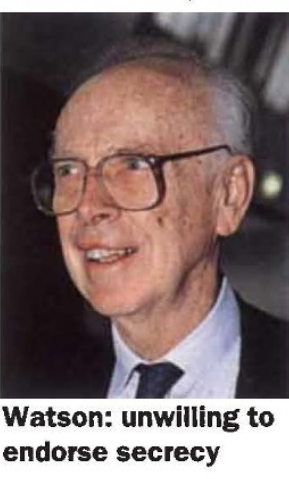

Luminy in France, speaking at a meeting on intellectual property and the human genome in Paris last week.

Few researchers have accepted HGS's terms since they were announced in October. James Watson, the Nobel prizewinner and director of Cold Spring Harbor Laboratory, said, for example, that he could not enforce a confidentiality agreement demanded by HGS, that would restrict discussions between different research groups working on HGS data, and that this would expose his institute to legal action.

David Owen, from the UK Medical Research Council (MRC), says that the council considers that HGS's terms "restrain interaction" and has not authorized its researchers to sign contracts with HGS. Like many other laboratories, the MRC is trying to negotiate better terms.

But patents may not be the end of the story. This was illustrated at the meeting by Rebecca Eisenberg, from the University of Michigan Law School in Ann Arbor, who pointed out that "substantial private funds" are now being committed to cDNA sequences on which no patent rights are held. This, says Eisenberg, is providing a "real world laboratory" for viewing the competing strategies of HGS, Incyte Pharmaceuticals, and Merck Sharpe \& Dohme for commercializing "unpatented" results from the genome. 